\title{
Analysis of the Policyholders' Perception on Claim and Settlement Procedures in Motor Insurance Business in Erode District
}

\author{
S. M. Jayasudha* \\ Associate Professor \& Head, Department of Business Administration, Vellalar College for Women, Erode, \\ Tamil Nadu, India; jayasudhasm1@gmail.com
}

\begin{abstract}
The fast administration of claims is both a legal obligation of an insurance company and a strong public relations and marketing strategy. The claim settlement in non-life insurance, thus, has its own peculiarities and therefore need proper handling. Claims arise when the insured's vehicle is damaged or any loss incurred, any legal liability is incurred for death of or bodily injury or damage to the property of a third party caused due to the usage of insured vehicle. Certain legal formalities are required to be undergone by the insured. These formalities slightly differ from one company to another. The present study analyses the Level of Perception of the respondents on Claim Procedures and Settlement Procedures followed in Motor Insurance.
\end{abstract}

Keywords: Claim, Motor Insurance, Settlement

\section{Introduction}

Claim is a right of insured to receive the amount secured under the policy of insurance contract promised by Insurer. The business of insurance is all about settling claims. Claims settlement, is the only reason the insured purchases an insurance product. The fast administration of Claims is therefore not only a legal obligation of an insurance company, but a strong Public relations and marketing strategy [1]. For any insurer, success is defined by the customers' experience around the claim. Around 15 per cent of policies in non-life insurance segment result in claim. The claim settlement in non-life insurance, thus, has its own peculiarities and therefore need proper handling. Hence the claims settlement record of an insurer is the benchmark of its performance. One area of operation that needs to be attended to with urgency in the non-life segment is motor insurance which paradoxically demonstrates high claims ratios, despite a surge in the levels of business progressively. There is need for all the stakeholders to find out ways to improve the performance of this class of insurance.

\section{Review of Literature}

Midha [2] revealed that in pursuance of the Claims Tribunal Agreed Procedure, compensation in more than 800 cases had been awarded by the Claims Tribunals to the claimants within 120 days. Ernst \& Young [3] stated that due to poor systems or inefficient processes, many insurers across Asia were simply not ready for the growth in claims that comes with premium growth. Companies that are performing well actively enhance their brand through the claims process. Manisha Modi [4] identified that the distribution of incurred claims ratio across the various segments of business was maximum in the

*Author for correspondence 
miscellaneous segment which includes motor insurance and this miscellaneous segment continued to incur the highest claims ratio. Rohit Kumar [5] identified that the private sector general insurance companies have comparatively shown more improvement than the public sector companies in terms of overall working, time taken to settle claim, procedure and formalities to settle claim, etc. Agrawal [6] highlighted that as on date, approximately 16 lakhs MACT cases were awaiting judgments from various courts. Fake claims, because of necessity of lodging FIR, police investigations, could also be ruled out. In a report by Capgemini [7], it was highlighted that for non-life insurers several inefficiencies-including aging technology, increasing process complexity, and a rising number of fraudulent claims-were driving up claims costs and adversely affecting customers' claims experience. Harry Ernest Boake Ofori - Attah [1], investigated the trends in company's (Enterprise Insurance Co. Ltd. - Takoradi Branch, Ghana,) claims settlement system and its effect on the sales and marketing of its insurance products. It was analysed that $80 / 133$ claims were settled within 3 months, 18/133 were settled in 4-6 months, whilst 5/133 claims were settled within 7-12 months, 6 were settled within 1 year and 24 in 2 years. As a result, $122 / 133$ of the respondents indicated that they were not satisfied. The rate of dissatisfaction increased with increasing period of claim settlement. Motor Insurance Handbook [8] stated that when a complaint is registered with IRDA, it facilitates resolution by taking it up with the insurance company. The company is given 15 days time to resolve the complaint. Seema Sharma \& Sujit Sikidar [9] analyzed the operating efficiency of the Public Sector Non-life Insurance Companies in the tariff free competitive market. The process of claim settlement in respect of Public Sector was more or less satisfactory and transparent but it was reported that the claim settlement procedure in Private Sector was not very transparent and healthy. Sometimes it was covered with suspicion and complaints. Qaiser [10] stressed that out of the total outgo on account of claims it is estimated that around 10 to 15 $\%$ is because of leakages, frauds and inflated claims. If this can be effectively checked, the benefit can be passed on to the customer by way of reduced premium rates.

Not many studies were undertaken on claim and settlement in motor insurance. The present study, therefore, aims at analyzing the opinion of the claimants on the procedures followed in claim and settlement.

\section{Statement of the Problem}

Motor Insurance for third party is mandated by the Motor Vehicles Act, 1988. As such the public gets insured with either the public sector companies or private sector companies. When a claim arises and is settled, the policyholder gets satisfied with the policy and the company. On the other hand, if a claim is unsettled, the policyholder may fail to adhere to the law. When the policyholders are satisfied, the insurance business grows. Thus, claim settlement is a major factor that influences the growth of Motor Insurance business. An attempt is therefore made to analyze the opinion of the policyholders towards claim settlement in Motor Insurance.

\section{Objective of the Study}

To analyse the respondents' opinion on the Claim and Settlement Procedures followed in Motor Insurance Business.

\section{Methodology}

The validity of any research is based on the systematic method of data collection and analysis. The present study uses both primary as well as secondary data. The primary data was collected from the policyholders of Motor Insurance who have claimed their insurer and settlement is made against their claim. The study is confined to Erode District only. Well structured questionnaire was prepared and circulated among 1000 respondents. Publications and Web resources provided the secondary data.

\section{Sample Design}

Five Taluks in Erode District were chosen at random viz., Sathyamangalam, Gobichettipalayam, Perundurai, Erode and Bhavani. In order to have equal representation, 200 respondents were selected from the Community Development Blocks of each of the taluks. Convenience Sampling Technique was adopted for the selection of sample respondents.

\section{Data Analysis}

The five-point Scale Scoring Technique and Friedman's Rank Test are used to analyse the collected data. The 
Friedman test is used for one-way repeated measures analysis of variance by ranks. The procedure involves ranking each row together, then considering the values of ranks by columns. The test statistic is given.

\section{Period Covered for the Study}

The study pertains to the period from April 2010 to June 2014.

\section{Analysis of Level of Perception of the Respondents on the Claim Procedures followed in Motor Insurance}

The Level of Perception on Claim Procedures has been measured by assigning scores to factors relating to perception on claim procedures. Few of the parameters taken from earlier studies [5, 8] have been modified to suit the present study. The results of five point Scale Scoring Technique are shown in Table 1.

\section{Interpretation}

From Table 1, it is inferred that majority (88.30per cent) of the respondents agree that the petition/claim is filed on time, followed by the accident is intimated to insurer on time (83.50per cent), verification of policy/ vehicular document is done promptly (81.20per cent) and the like. The majority (67.70per cent) of the respondents have neither agreed nor disagreed that the claim matter/ MACT cases is entrusted to an advocate, followed by FIR/GD entry is lodged immediately (49.40per cent), the estimate of repair charges is disputed by insurer (46.40per cent) and the like. Among other factors, maximum

Table 1. Level of perception of the respondents on claim procedures in motor insurance (Scale Scoring Technique)

\begin{tabular}{|c|c|c|c|c|c|c|}
\hline S. No. & Procedures & SA & A & $\mathrm{N}$ & $\mathrm{DA}$ & SDA \\
\hline 1 & The accident is intimated to insurer on time & $\begin{array}{c}422 \\
(42.20)\end{array}$ & $\begin{array}{c}413 \\
(41.30)\end{array}$ & $\begin{array}{c}141 \\
(14.10)\end{array}$ & $\begin{array}{c}17 \\
(1.70)\end{array}$ & $\begin{array}{c}7 \\
(0.70)\end{array}$ \\
\hline 2 & Sufficient guidance is provided by the insurer & $\begin{array}{c}267 \\
(26.70) \\
\end{array}$ & $\begin{array}{c}526 \\
(52.60) \\
\end{array}$ & $\begin{array}{c}159 \\
(15.90) \\
\end{array}$ & $\begin{array}{c}48 \\
(4.80) \\
\end{array}$ & $\begin{array}{c}0 \\
(0.00) \\
\end{array}$ \\
\hline 3 & $\begin{array}{c}\text { The admissibility of damage is considered fully for } \\
\text { claiming }\end{array}$ & $\begin{array}{c}191 \\
(19.10) \\
\end{array}$ & $\begin{array}{c}391 \\
(39.10) \\
\end{array}$ & $\begin{array}{c}331 \\
(33.10) \\
\end{array}$ & $\begin{array}{c}74 \\
(7.40) \\
\end{array}$ & $\begin{array}{c}13 \\
(1.30) \\
\end{array}$ \\
\hline 4 & $\begin{array}{l}\text { The policy documents are thoroughly checked by } \\
\text { insurer }\end{array}$ & $\begin{array}{c}261 \\
(26.10)\end{array}$ & $\begin{array}{c}450 \\
(45.00) \\
\end{array}$ & $\begin{array}{c}231 \\
(23.10) \\
\end{array}$ & $\begin{array}{c}52 \\
(5.20) \\
\end{array}$ & $\begin{array}{c}6 \\
(0.60) \\
\end{array}$ \\
\hline 5 & The petition/claim is filed on time & $\begin{array}{c}364 \\
(36.40) \\
\end{array}$ & $\begin{array}{c}519 \\
(51.90) \\
\end{array}$ & $\begin{array}{c}104 \\
(10.40) \\
\end{array}$ & $\begin{array}{c}13 \\
(1.30) \\
\end{array}$ & $\begin{array}{c}0 \\
(0.00) \\
\end{array}$ \\
\hline 6 & The claim form is issued promptly on intimation & $\begin{array}{c}239 \\
(23.90)\end{array}$ & $\begin{array}{c}527 \\
(52.70) \\
\end{array}$ & $\begin{array}{c}194 \\
(19.40) \\
\end{array}$ & $\begin{array}{c}33 \\
(3.30) \\
\end{array}$ & $\begin{array}{c}7 \\
(0.70) \\
\end{array}$ \\
\hline 7 & $\begin{array}{c}\text { The estimate of repair charges is disputed by } \\
\text { insurer }\end{array}$ & $\begin{array}{c}96 \\
(9.60) \\
\end{array}$ & $\begin{array}{c}209 \\
(20.90)\end{array}$ & $\begin{array}{c}464 \\
(46.40) \\
\end{array}$ & $\begin{array}{c}160 \\
(16.00) \\
\end{array}$ & $\begin{array}{c}71 \\
(7.10) \\
\end{array}$ \\
\hline 8 & Surveyor is appointed immediately & $\begin{array}{c}304 \\
(30.40)\end{array}$ & $\begin{array}{c}363 \\
(36.30)\end{array}$ & $\begin{array}{c}317 \\
(31.70)\end{array}$ & $\begin{array}{c}16 \\
(1.60)\end{array}$ & $\begin{array}{c}0 \\
(0.00)\end{array}$ \\
\hline 9 & $\begin{array}{c}\begin{array}{c}\text { Surveyor thoroughly inspected the damaged vehi- } \\
\text { cle before repairing }\end{array} \\
\end{array}$ & $\begin{array}{c}308 \\
(30.80)\end{array}$ & $\begin{array}{c}345 \\
(34.50)\end{array}$ & $\begin{array}{c}315 \\
(31.50) \\
\end{array}$ & $\begin{array}{c}25 \\
(2.50) \\
\end{array}$ & $\begin{array}{c}7 \\
(0.70) \\
\end{array}$ \\
\hline 10 & FIR/GD entry is lodged immediately & $\begin{array}{c}368 \\
(36.80) \\
\end{array}$ & $\begin{array}{c}79 \\
(7.90) \\
\end{array}$ & $\begin{array}{c}494 \\
(49.40) \\
\end{array}$ & $\begin{array}{c}25 \\
(2.50) \\
\end{array}$ & $\begin{array}{c}34 \\
(3.40)\end{array}$ \\
\hline 11 & Investigation is carried out thoroughly & $\begin{array}{c}247 \\
(24.70) \\
\end{array}$ & $\begin{array}{c}380 \\
(38.00) \\
\end{array}$ & $\begin{array}{c}315 \\
(31.50) \\
\end{array}$ & $\begin{array}{c}45 \\
(4.50) \\
\end{array}$ & $\begin{array}{c}13 \\
(1.30)\end{array}$ \\
\hline 12 & $\begin{array}{c}\text { Driving license, RC, Permit, tax challan, Badge etc. } \\
\text { is verified immediately }\end{array}$ & $\begin{array}{c}341 \\
(34.10) \\
\end{array}$ & $\begin{array}{c}385 \\
(38.50) \\
\end{array}$ & $\begin{array}{c}226 \\
(22.60) \\
\end{array}$ & $\begin{array}{c}48 \\
(4.80) \\
\end{array}$ & $\begin{array}{c}0 \\
(0.00) \\
\end{array}$ \\
\hline 13 & $\begin{array}{l}\text { Verification of policy / vehicular document is done } \\
\text { promptly }\end{array}$ & $\begin{array}{c}336 \\
(33.60) \\
\end{array}$ & $\begin{array}{c}476 \\
(47.60) \\
\end{array}$ & $\begin{array}{c}150 \\
(15.00) \\
\end{array}$ & $\begin{array}{c}38 \\
(3.80) \\
\end{array}$ & $\begin{array}{c}0 \\
(0.00) \\
\end{array}$ \\
\hline 14 & $\begin{array}{l}\text { The claim matter / MACT cases is entrusted to an } \\
\text { advocate }\end{array}$ & $\begin{array}{c}163 \\
(16.30)\end{array}$ & $\begin{array}{c}139 \\
(13.90)\end{array}$ & $\begin{array}{c}677 \\
(67.70)\end{array}$ & $\begin{array}{c}12 \\
(1.20)\end{array}$ & $\begin{array}{c}9 \\
(0.90\end{array}$ \\
\hline
\end{tabular}

SA - Strongly Agree, A - Agree, N - Neither Agree Nor Disagree, DA - Disagree, SD - Strongly Disagree 
(23.10per cent) respondents disagree that the estimate of repair charges is disputed by insurer, followed by the admissibility of damage is considered fully for claiming (8.70per cent), FIR/GD entry is lodged immediately and the like.

In order to determine the factors that highly influenced the perception level of the respondents, Friedman's rank test is used and the results are shown in Table 2.

\subsection{Test Statistics(a)}

\begin{tabular}{|c|c|}
\hline N & 1000 \\
Chi-Square & 1663.416 \\
Df & 13 \\
Asymp. Sig. & .000 \\
\hline
\end{tabular}

a Friedman's Test

Table 2. Result of friedman's rank test on level of perception on claim procedures in motor insurance

\begin{tabular}{|c|c|c|c|}
\hline S.No. & Procedures & Mean Rank & Rank \\
\hline 1 & The accident is intimated to insurer on time & 9.23 & 1 \\
\hline 2 & Sufficient guidance is provided by the insurer & 8.21 & 4 \\
\hline 3 & The admissibility of damage is considered fully for claiming & 6.60 & 12 \\
\hline 4 & The policy documents are thoroughly checked by insurer & 7.67 & 9 \\
\hline 5 & The petition/claim is filed on time & 9.12 & 2 \\
\hline 6 & The claim form is issued promptly on intimation & 7.91 & 6 \\
\hline 7 & The estimate of repair charges is disputed by insurer & 4.51 & 14 \\
\hline 8 & Surveyor is appointed immediately & 7.78 & 7 \\
\hline 9 & Surveyor thoroughly inspected the damaged vehicle before repairing & 7.76 & 8 \\
\hline 10 & FIR/GD entry is lodged immediately & 6.77 & 11 \\
\hline 11 & Investigation is carried out thoroughly & 7.18 & 10 \\
\hline 12 & Driving license, RC, Permit, tax challan, Badge etc. is verified immediately & 8.20 & 5 \\
\hline 13 & Verification of policy /vehicular document is done promptly & 8.68 & 3 \\
\hline 14 & The claim matter / MACT cases is entrusted to an advocate & 5.39 & 13 \\
\hline
\end{tabular}

\subsection{Interpretation}

Of the various procedures followed in claim, the formality of intimation of the accident to insurer on time ranked first, followed by Petition/Claim is filed on time, Verification of policy /vehicular document is done promptly, Sufficient guidance is provided by the insurer, Driving license, RC, Permit, Tax challan, Badge etc. is verified immediately, The claim form is issued promptly on intimation, Surveyor is appointed immediately, Surveyor thoroughly inspected the damaged vehicle before repairing, The policy documents are thoroughly checked by insurer, Investigation is carried out thoroughly, FIR/GD entry is lodged immediately. The admissibility of damage is considered fully for claiming and The claim matter/MACT cases is entrusted to an advocate is ranked the least.

\section{Analysis of Level of Perception of the Respondents on the Settlement Procedures followed in Motor Insurance}

The Level of Perception on Settlement Procedures has been measured by assigning scores to factors relating to perception on Settlement Procedures. Parameters taken from earlier studies $[8,10]$ have been modified for the purpose of present study. Scale Scoring Technique is applied and the results are shown in Table 3

\subsection{Interpretation}

From Table 3, it is observed that majority (74.50per cent) of the respondents agree that there is Prompt Surveyor appointment and survey report submission, followed by 
Table 3. Level of Perception on settlement procedures in motor insurance (Scale Scoring Technique)

\begin{tabular}{|c|c|c|c|c|c|}
\hline S.No. & Procedures & A & $\mathrm{N}$ & DA & SDA \\
\hline 1 & $\begin{array}{l}\text { Prompt Surveyor appointment and survey report } \\
\text { submission }\end{array}$ & $\begin{array}{c}458 \\
(45.80)\end{array}$ & $\begin{array}{c}234 \\
(23.40)\end{array}$ & $\begin{array}{c}14 \\
(1.40)\end{array}$ & $\begin{array}{c}7 \\
(0.70)\end{array}$ \\
\hline 2 & Re-survey of damage is felt not necessary & $\begin{array}{c}339 \\
(33.90)\end{array}$ & $\begin{array}{c}416 \\
(41.60)\end{array}$ & $\begin{array}{c}23 \\
(2.30)\end{array}$ & $\begin{array}{c}19 \\
(1.90)\end{array}$ \\
\hline 3 & On dispute, Second Surveyor is felt necessary & $\begin{array}{c}168 \\
(16.80)\end{array}$ & $\begin{array}{c}460 \\
(46.00)\end{array}$ & $\begin{array}{c}161 \\
(16.10) \\
\end{array}$ & $\begin{array}{c}101 \\
(10.10) \\
\end{array}$ \\
\hline 4 & The loss assessment is assessed accurately & $\begin{array}{c}402 \\
(40.20) \\
\end{array}$ & $\begin{array}{c}294 \\
(29.40) \\
\end{array}$ & $\begin{array}{c}47 \\
(4.70) \\
\end{array}$ & $\begin{array}{c}46 \\
(4.60) \\
\end{array}$ \\
\hline 5 & The loss is indemnified promptly & $\begin{array}{c}358 \\
(35.80) \\
\end{array}$ & $\begin{array}{c}295 \\
(29.50) \\
\end{array}$ & $\begin{array}{c}58 \\
(5.80) \\
\end{array}$ & $\begin{array}{c}48 \\
(4.80) \\
\end{array}$ \\
\hline 6 & Mode of settlement proved to be effective & $\begin{array}{c}226 \\
(22.60) \\
\end{array}$ & $\begin{array}{c}347 \\
(34.70) \\
\end{array}$ & $\begin{array}{c}51 \\
(5.10) \\
\end{array}$ & $\begin{array}{c}12 \\
(1.20) \\
\end{array}$ \\
\hline 7 & The repair is carried out to your satisfaction & $\begin{array}{c}261 \\
(26.10) \\
\end{array}$ & $\begin{array}{c}399 \\
(39.90) \\
\end{array}$ & $\begin{array}{c}31 \\
(3.10) \\
\end{array}$ & $\begin{array}{c}33 \\
(3.30) \\
\end{array}$ \\
\hline 8 & The repaired vehicle is a good replacement & $\begin{array}{c}342 \\
(34.20) \\
\end{array}$ & $\begin{array}{c}500 \\
(50.00) \\
\end{array}$ & $\begin{array}{c}21 \\
(2.10) \\
\end{array}$ & $\begin{array}{c}19 \\
(1.90) \\
\end{array}$ \\
\hline 9 & Loss is indemnified commiserating the estimate & $\begin{array}{c}312 \\
(31.20)\end{array}$ & $\begin{array}{c}387 \\
(38.70)\end{array}$ & $\begin{array}{c}93 \\
(9.30) \\
\end{array}$ & $\begin{array}{c}40 \\
(4.00) \\
\end{array}$ \\
\hline 10 & $\begin{array}{l}\text { Pending cases were placed before Lok Adalat/ } \\
\text { Common Mechanism/ Out of court settlement }\end{array}$ & $\begin{array}{c}203 \\
(20.30)\end{array}$ & $\begin{array}{c}65 \\
(65.60) \\
\end{array}$ & $\begin{array}{c}56 \\
(5.60) \\
\end{array}$ & $\begin{array}{c}13 \\
(1.30) \\
\end{array}$ \\
\hline
\end{tabular}

SA - Strongly Agree, A - Agree, N - Neither Agree Nor Disagree, DA - Disagree, SD - Strongly Disagree

loss assessment is assessed accurately (61.30per cent), the loss is indemnified promptly (59.90per cent) and the like. The majority (65.60per cent) of the respondents neither agree nor disagree that Pending cases were placed before Lok Adalat/Common Mechanism/ Out of court settlement, followed by the repaired vehicle is a good replacement (50per cent), On dispute, Second Surveyor is felt necessary (46per cent) and the like. Among other variables, the maximum (26.20 per cent) respondents disagree that on dispute, Second Surveyor is felt necessary, followed by Loss is indemnified commiserating the estimate (13.30per cent) and the like.

In order to determine the factors that highly influenced the Perception level of the respondents on the Settlement Procedures, Friedman's rank test is used and the results are shown in Table 4.

\subsection{Test Statistics(a)}

\begin{tabular}{|c|c|}
\hline N & 1000 \\
Chi-Square & 912.144 \\
Df & 9 \\
Asymp. Sig. & .000 \\
\hline
\end{tabular}

a Friedman's Test

\subsection{Interpretation}

From the Friedman's rank test it is found that, of the various Settlement Procedures, prompt Surveyor appointment and survey report submission ranked first, followed by Mode of settlement proved to be effective, the repair is carried out to their satisfaction, The loss assessment is assessed accurately, The loss is indemnified promptly, Re-survey of damage is felt not necessary, The repaired vehicle is a good replacement, Loss is indemnified commiserating the estimate, Pending cases were placed before Lok Adalat/Common Mechanism/ Out of court settlement and On dispute, Second Surveyor was felt necessary is ranked the least.

\section{Conclusion}

In the above analysis, the Level of Perception of the respondents on the claim and settlement procedures is studied. The analysis highlights that the insurers promptly recorded the claims and processed them. The settlement is done promptly. To maintain market share and profitability, in a highly competitive insurance market, differentiation through new and more effective claims management practices is considered to be one of the most important and effective ways. Sophisticated 
Table 4. Result of Friedman's rank test on level of perception on settlement procedures in motor insurance

\begin{tabular}{|c|c|c|c|}
\hline S. No. & Procedures & Mean Score & Rank \\
\hline 1 & Prompt Surveyor appointment and survey report submission & 6.71 & 1 \\
\hline 2 & Re-survey of damage is felt not necessary & 5.65 & 6 \\
\hline 3 & On dispute, Second Surveyor is felt necessary & 4.14 & 10 \\
\hline 4 & The loss assessment is assessed accurately & 5.79 & 4 \\
\hline 5 & The loss is indemnified promptly & 5.79 & 4 \\
\hline 6 & Mode of settlement proved to be effective & 6.42 & 2 \\
\hline 7 & The repair is carried out to your satisfaction & 5.85 & 3 \\
\hline 8 & The repaired vehicle is a good replacement & 5.15 & 7 \\
\hline 9 & Loss is indemnified commiserating the estimate & 8 \\
\hline 10 & Pending cases were placed before Lok Adalat/Common Mechanism/ Out & 4.39 & 9 \\
\hline
\end{tabular}

insurers need to probe trends and patterns in past claims experience that may assist them to re-price products, assess distribution channels' performance and spot the most profitable customer segments.

\section{References}

1. Harry Ernest Boake Ofori - Attah. "The effects of slow claims settlement on the sales and marketing of insurance products: A case study of Enterprise Insurance Co. Ltd. Takoradi Branch, Ghana". Available: http://ir.knust.edu.gh/ bitstream/123456789/4425/1/Harry\%20Ernest\%20B.\%20 Ofori-Attah.pdf

2. Midha, J.R. "Motor Accident Claims Referencer". Delhi Judicial Academy, 2011, pp. 52-56.

3. Ernst \& Young- Motor Insurance Asia’s growth engine "Claims Management", 2011, pp. 28-29.

4. Manisha M. "A comparative performance study of general insurance Public sector companies of India”. Available: http://etheses.saurashtrauniversity.edu/95/, 2011.

5. Rohit K. "Performance evaluation of General Insurance Companies: a study of post-reform period". Available: http://shodhganga.inflibnet.ac.in/handle/10603/2352, 2011

6. Agrawal M.C. "Motor Third Party-Need to view differently", The Insurance Times, 2012.
7. The news item, "Emerging Trends in Non-Life Insurance: Claims", Global Trends in Non-Life Insurance: Claims", Capgemini, Consulting, technology and outsourcing services provider, 2012, p. 6 .

8. Motor Insurance Handbook, 2012. Available: http://www. policyholder.gov.in/uploads/CEDocuments/Motor\%20English.pdf

9. Seema S., and Sujit S. "Performance measurement of Public sector insurance units after de-tariffication". Journal of Business Management \& Social Sciences Research, Vol. 3(3), pp. 44-50, 2014.

10. Qaiser R. "Claims Management in General Insurance - Issues \& Concerns”, 2012. Available: http://www.niapune. com/pdfs/Research/Claims\%20Management.pdf

\section{Appendix}

- $\quad$ FIR/GD - First Information Report/General Diary

- $\quad$ MACT - Motor Accident Claims Tribunal

- $\mathrm{RC}-$ Registeration Certificate

- $\quad$ IRDA - Insurance Regulatory \& Development Authority 